\title{
Taxonomic revision of Chamaepinnularia krookiformis LANGE-BERTALOT et KRAMMER with a description of Chamaepinnularia plinskii sp. nov.
}

\author{
Joanna ŻELAZNA-WIECZOREK \& Rafał M. OLSZYŃSKI
}

University of Łódź, Faculty of Biology and Environmental Protection, Department of Algology and Mycology, PL-90-237 Łódź, 12/16 Banacha St.; Corresponding author e-mail: zelazna@biol.uni.lodz.pl

\begin{abstract}
The benthic diatoms collected during our recent research in athalassic habitats exemplify a high morphological variability within Chamaepinnularia krookiformis LANGE-BERTALOT et KRAMMER. The species has already been known from freshwater ecosystems as well as from brackish waters in different regions of Europe. This variability has been also confirmed by the analysis of the literature. However, this is the first time that the morphological variability of the species has been addressed. In order to revise C. krookiformis and describe a new species, which has been distinguished on the basis of our material, we compared it with the type material of Pinnularia krookiformis KRAMMER 1992 from the periodic saline pool in Nordrhein-Westfalen (Germany). This study deals with a morphological analysis based on a large populations of C. krookiformis from Pełczyska (Central Poland). Selected morphological features were analysed, i.e.: valve length and width, number of striae in $10 \mu \mathrm{m}$, apices width, constrictions width, apices/constrictions width ratio, central-area length, and valve/central area length ratio. The results of light (LM) and scanning (SEM) microscopy, supported by multidimensional scaling (MDS), allowed for the distinction of three different morphotypes. Two of them match Krammer concept of Pinnularia krookiformis from 1992, while the third, occurring in our samples in three sampling sites, is clearly different. Thus, we described a new species Chamaepinnularia plinskii sp. nov., by the following major features: the valves are linear, symmetric, with rounded, capitate apices, the axial area is narrow, expanding to a wide central area forming a fascia, distal raphe endings are hooked to the same side of the valve and striae slightly radiate in the middle and in the rounded apices, becoming parallel in constrictions, 20-26 in $10 \mu \mathrm{m}$. This species occurs in inland waters with a wide range of chloride concentration, from 1000 to $3500 \mathrm{mg} \cdot \mathrm{l}^{-1}$.
\end{abstract}

Key words: brackish inland waters, Pinnularia, Chamaepinnularia, type material, new species

\section{INTRODUCTION}

The Chamaepinnularia Lange-Bertalot et Krammer genus was described in 1996, based on generitype Chamaepinnularia vyvermanii LANGE-BERTALOT et KRAMMER from the periodic saline pool in NordrheinWestfalen (Germany). According to the first description, representatives of the genus are characterized by small cells with their dimension not exceeding 25 $\mu \mathrm{m}$ in length and $4 \mu \mathrm{m}$ in width (Lange-Bertalot \& MetZeltin 1996); a slightly larger dimension range is characteristic for Chamaepinnularia gerlachei VAN DE ViJver et Sterken from Antarctica (VAn de ViJver et al. 2010).

Diatom frustules of this genus are linear through linear-elliptic to linear-lanceolate shapes with rounded apices. The symmetry and arrangement of the raphe system do not deviate significantly from those observed in representatives of Navicula BORY de Saint-Vincent and Pinnularia Ehrenberg. Distal raphe endings are hooked towards the same direction. Proximal raphe endings are deflected. Distal raphe arms terminate on a helictoglossa on the valve internal side, while the proximal raphe endings are hooked. Externally, distinguishable single-row striae are formed out of one large areola create foramina, occluded by vela. Internally, striae are open with silica bridges (Lange-Bertalot \& Metzeltin 1996; Wetzel et al. 2013).

The genus include species, which were earlier classified as Navicula or Pinnularia (LANGE-BerTALOT \& MetZeltin 1996), e.g. those within the Navicula genus - Chamaepinnularia begeri (KRASSKE) LANGEBertalot, C. mediocris (Krasske) Lange-Bertalot, C. soehrensis (Krasske) Lange-Bertalot et Krammer and those within the Pinnularia genus - Chamaepin- 
nularia krookii (KRAMMER) LANGE-BERTALOT et KARMMER, C. krookiformis (Krammer) LANGE-Bertalot et KARMMER. Recently, Chamaepinnularia parsura (HusTEDT) C.E. Wetzel et Ector, C. obsoleta (Hustedt) C.E. Wetzel et Ector, C. brevissima (Hustedt) C.E. Wetzel et Ector, $C$. perfidissima (Lange-Bertalot) C.E. Wetzel et Ector, and $C$. ventosa (Hustedt) C.E. Wetzel et Ector (Wetzel et al. 2013) were transferred to Chamaepinnularia.

Chamaepinnularia species occur in various fresh-water habitats and in waters with a varying range of salinity. Several species are typical of aerial habitats. Species occurring in antarctic regions are also known (VAn DE ViJVER et al. 2010; Sterken et al. 2015). Some species were observed in the Sphagnum peat bogs (KULIKOvSKIY et al. 2010). In Europe, Chamaepinnularia schauppiana LANGE-BERTAlot et METZELtin was noted to occur in oligo-dystrophic waters in Finland but also in mire and fen pools (CANTONATI \& LANGE-BERTALOT 2009). It was also observed that several other species occurred in Europe both in low pH lakes (KAPETANOvić et al. 2011) and in mountain fens with a high concentration of minerals (FrÁNKOVÁ et al. 2009).

Chamaepinnularia krookiformis was noted to occur in the area of Poland both in seawaters and saline inland waters in the coastal zone (WITKOWSKI 1994; WITKOWsKI et al. 2000; BĄK et al. 2006), in freshwater ecosystem such as upland rivers (Wojtal 2009; Peszek et al. 2015), quaternary springs located near Łódź (ŻELAZNAWieczoreK 2011), and in athalassic habitats in Central Poland (ŻelaZnA-WieczoreK et al. 2015).

For many years, specimens of Chamaepinnularia krookiformis and $C$. krookii have been classified into different genera and species (Fig. 1). Navicula krockii was first described in 1882 by Grunow. The description contained information about a similarity of the species with Pinnularia globiceps GREGORY (1856). The valve length was within 19-28 $\mu \mathrm{m}$, its width was between 5.5 and $7 \mu \mathrm{m}$. The number of striae was between 15 and 17 in $10 \mu \mathrm{m}$ (GRUNOw 1882). Several years later, CLEVE (1891) transferred the species to the genus Pinnularia, at the same time introducing a correction in the species name giving it the name of Pinnularia krookii CLEVE. The species' name was given to honour Swedish botanist Krook (Cleve 1891). Several years later, CLEve (1895) considered P. krookii to be a variety of P. globiceps: P. globiceps var. krookii CLEVE. The change resulted from the similarity of $P$. krookii to $P$. globiceps; the most significant difference was that of the cell size (CLEVE 1895). Navicula ignobilis KRASSKE was described in 1938. However, specimens shown in the drawing were very similar to the specimen drawing of Navicula krockii Grunow published in 1882 (GrunOw 1882; KraSSKe 1938). KRAMMER and LANGE-BERTALOT (1986), who referred to some earlier works by GRUNOw (1882), CLEVE (1895) and KRASSKE (1938) marked Pinnularia "krocki" and Pinnularia ignobilis. Under the name of Pinnularia ignobilis, pic- tures showing in fact Pinnularia "krocki" (Krammer, LANGE-Bertalot 1986, p. 416-417, tafel 187, figs 6-7, 9'; tafel 206, figs 12-19) were published. While photomicrographs of Pinnularia "krocki" KRAMMER, LANGEBertalot (1986, p. 416, tafel 187, fig. 9; tafel 206, figs 8-9) showed the species that had not been previously described. Krammer (1992) described a new species of Pinnularia krookiformis making a reference to the specimens illustrated in the publication of KRAMMER \& LANGE-Bertalot (1986, p. 416, tafel 187, fig. 9; tafel 206, figs 8-9). Several years later, P. krookii and $P$. krookiformis were transferred to the Chamaepinnularia genus by LANGE-BERTALOT et KRAMMER in LANGEBertalot \& Genkal (1999) (see Fig. 1).

In this paper, we present results of the analysis of populations of Chamaepinnularia krookiformis from the Pełczyska (Central Poland) and the type material Pinnularia krookiformis from Nordrhein-Westfalen (Germany) described by KRAMMER (1992) with light (LM) and scanning electron microscope (SEM) techniques using multivariate analysis of multidimensional scaling (MDS) to explore the morphological variability of the different populations up to now identified as $C$. krookiformis. The analysis enabled us to describe one new species Chamaepinnularia plinskii sp. nov., which is detailed below.

\section{Material ANd Methods}

The study area is located in Pełczyska $\left(51^{\circ} 58^{\prime} 34.5^{\prime \prime} \mathrm{N}\right.$, $\left.19^{\circ} 14^{\prime} 20.4^{\prime \prime E}\right)$ (Central Poland), a village next to the city of Łęczyca in the Łódź Province. The study area included three sampling sites, i.e. outflow, ditch and pond, with a varying range of salinity. Chemical and physical parameters, also the structure of diatom assemblages, clearly differentiate the ditch environment from the two other ecosystems of an outflow and pond (ŻELAZNA-WIECZOREK et al. 2015). All the data is compiled in Table 1 .

The following samples have been examined. 30 samples altogether were collected from all three habitats in 1964 (X, XI and XII); 1992 (IV); 1994 (VI, IX); 2013 (VII, XII); 2014 (II, III). For the diatomological analysis, 15 samples collected by PLIŃSKI in 1964/1965 (1969), 3 samples collected by ŻelaZnA-WieCZOREK (2002) in 1992/1994, and 12 samples collected recently, in 2013/2014, were used. The morphological analysis was based on samples in which Chamaepinnularia krookiformis occurred with relative abundance greater than $5 \%$. The recent benthic samples were collected and purified according to ŻELAZNA-WIECZOREK (2011).

The analysis of selected morphological features of Chamaepinnularia krookiformis was made by examining 4 permanent slides with a light microscope (Nikon YS 100 and Nikon Eclipse E400) with 1000× magnification (plan oil-immersion objective $100 \times / 1.25$ ). A total of 170 specimens were analysed in 4 permanent slides. The following features were taken into account: 1) valve width and 2) length, 3 ) number of striae in $10 \mu \mathrm{m}, 4)$ width of capitate apices, 5) width of constrictions, 6) ratio of apices width and constrictions width, 7) length of central area and 8) ratio of valve length and central 
area length (Fig. 2A) in the MDS analysis (Multi-Dimensional-Scaling - MDS) based on the BRAY-CURTIS similarity (ŻELAZNA-WIECZOREK 2011) was used. The PRIMER 6.1.10 software was used for calculations.

The new permanent slides from unmounted type material of Pinnularia krookiformis KRAMMER 1992 from saline puddles in Nordrhein-Westfalen were prepared (Salzgebiet südlich von Salzkotten, Nordrhein-Westfalen Germany, leg. Wygasch, 17.04.1982 - KR604B Friedrich-HustedtZentrum für Diatomeenforschung Institute for Polar and Marine Research, Bremerhaven). The unmounted sample was washed, first in $95 \%$ ethyl alcohol and then several times in deionized water. The new permanent slides were mounted with Naphrax ${ }^{\circledR}$ according to ŻELAZNA-WIECZOREK (2011). 45 specimens from the type material morphological features were analysed.

All materials were analysed using the Phenom Pro X (with $8 \mathrm{~nm}$ gold layer, at $10 \mathrm{kV}$ ) scanning microscope at the Laboratory of Microscopy Imaging \& Specialist Biological Techniques at Faculty of Biology \& Environmental Protection. SEM photomicrographs were taken at a resolution of $1024 \times 1080$ pixels

\section{Results AND Discussion}

The BraY-CuRTIS similarity index was used to determine the similarity between Chamaepinnularia krookiformis specimens. The MDS procedure distinguished three groups of specimens determined as: Morphotype $1(\mathrm{~N}=66$ specimens), Morphotype $2(\mathrm{~N}=66$ specimens) and Morphotype 3 ( $\mathrm{N}=38$ specimens) (Fig. 2B.). The variation range of morphological features of specimens and species variability by LANGE-BERTALOT \& GeNKAL (1999) are listed in Table 2.

\section{Chamaepinnularia plinskii ŻelazNa-WieczoreK et OlsZYŃski sp. nov. (Figs. 3-19) \\ Morphotype 1 (Fig. 2B)}

Synonyms: Pinnularia spec. in: Krammer, K. \& Lange-Bertalot, H. 1986 pro parte: fig. 206: 10;

Pinnularia krooki in: Krammer, K. 1992 pro parte: tafel: 18, fig. 2; Pinnularia krookiformis Krammer 1992, in: WitKowsKi, A. 1994 pro parte: plate: XXXVIII, figs 16-17.

Description: LM: Linear, symmetric valves with rounded capitate apices. Valve dimension: length 18 $24 \mu \mathrm{m}$, width 4-5 $\mu \mathrm{m}$, width of apices: $3-4 \mu \mathrm{m}$. The narrowest points of the valves are close to the capitate apices, width of constrictions $2.5-3.5 \mu \mathrm{m}$. The ratio of the width of apices to the width of constrictions is 0.9 1.4. The axial area is narrow, length $6-11 \mu \mathrm{m}$, width $3-5 \mu \mathrm{m}$, and expands to a wide central area, forming a fascia. The ratio of the valve length to the length of the central area is 1.9-3.4. Raphe is straight and filiform. Distal raphe endings are hooked towards the same direction. Proximal raphe endings are straight, expanded and pore-like. Striae are slightly-radiate in the middle and in the rounded apices to become parallel in the constrictions: $20-26$ in $10 \mu \mathrm{m}$.
SEM: Externally, striae are composed of a chamberlike areola and covered by vela. Striae on the valve face are separated from the mantle striae by a hyaline area (Fig. 50). Distal raphe endings are hooked, curving down to the mantle (Fig. 51). Internally, striae on the valve face are interrupted and divided by a silica bridge to form two parts, the first one is small and rounded, and located on the valve face-mantle junction, while the second one is elongated, and located on the valve face (Fig. 52). Proximal raphe endings are hooked and deflected to the same direction, distal raphe endings terminate in a helictoglossa. The thick sternum expands proximally to a wide, rhomboidal fascia, distally to polar bars (Fig. 52).

Holotype: slide: D.PEDB040713 No. 00065 Algae Collection Department of Algology and Mycology, University of Łódź. Holotype illustrated in Fig. 7 (designated here).

Type locality: POLAND. Łódź Province, Pełczyska village N 51 ${ }^{\circ} 58^{\prime} 34.5^{\prime \prime}$, E 19¹4'20.4", brackish inland waters.

Etymology: This species is named in honour of Professor Marcin PLIŃSKI, a Polish phycologist, who began exploring diatoms in Pełczyska village in 1964.

Differential diagnosis: Chamaepinnularia plinskii possesses the characteristic feature of the genus, i.e. a chamber-like areola covered by vela divided into two parts by a silica bridge on the internal valve side (Lange-Bertalot \& Metzeltin 1996). Unlike $C$. krookiformis, C. plinskii has wide fascia reaching the valve edge, a greater number of striae in $10 \mu \mathrm{m}$, wider constrictions and a lower ratio of the valve length to the width of the central area as shown in Table 2. C. plinskii may be also confused with Pinnularia bertrandii KRAMMER. However, $P$. bertrandii has a smaller number of striae in $10 \mu \mathrm{m}$, these are arranged more radially and they are shorter at the axial area apices. Frustules in $P$. bertrandii are larger and proximal endings of the raphe are slightly curved towards the same direction (Krammer 2000). Specimens similar to C. pliński were not found in the type material of Pinnularia krookiformis.

Ecology and Distribution: A description of Chamaepinnularia plinskii was made based on specimens mainly from a small ditch through which water flows from the backfilled outflow. The water is characterized by slightly alkaline to alkaline conditions and high conductivity values up to $5170 \mu \mathrm{S} . \mathrm{cm}^{-1}$. The concentration of chlorides varied from 1000 to $3500 \mathrm{mg} \cdot \mathrm{l}^{-1}$. As far as the type locality is concerned, this species was primarily found in benthic samples taken from the bottom of the ditch. C. plinskii was already reported in the freshwater springs of the Łódź Hills (ŻELAZNAWIECZOREK 2011, p. 103, plate 103, fig. 34) wherein the concentration of chlorides was between 12.09 


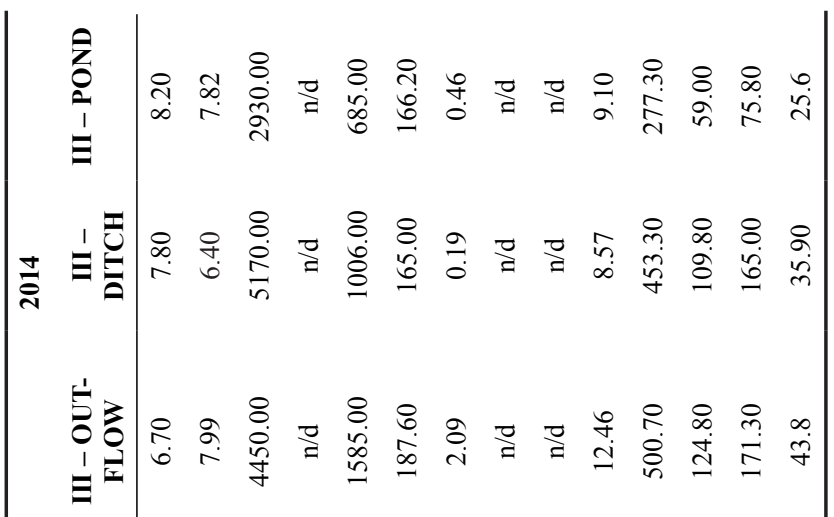

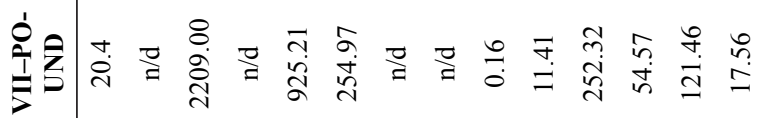

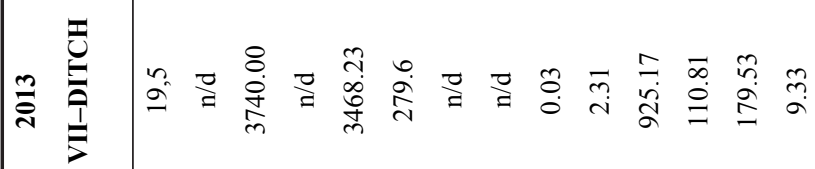

䍃

పे

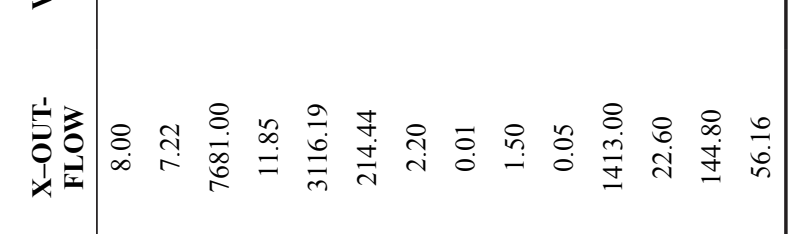

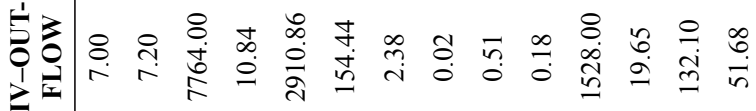

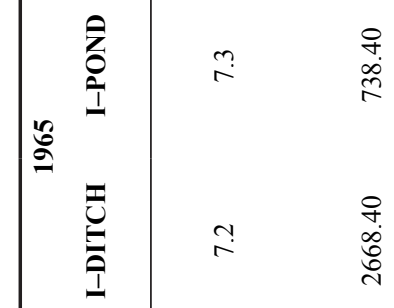

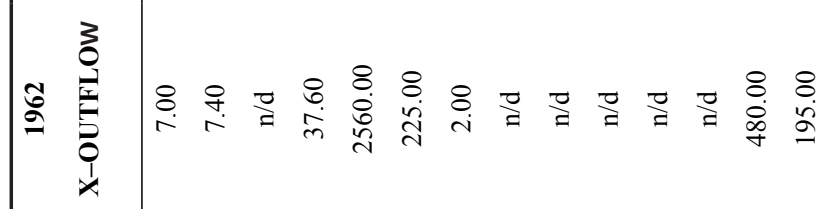

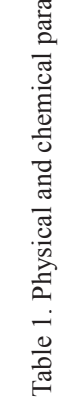

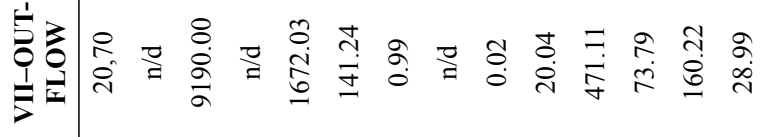
. 


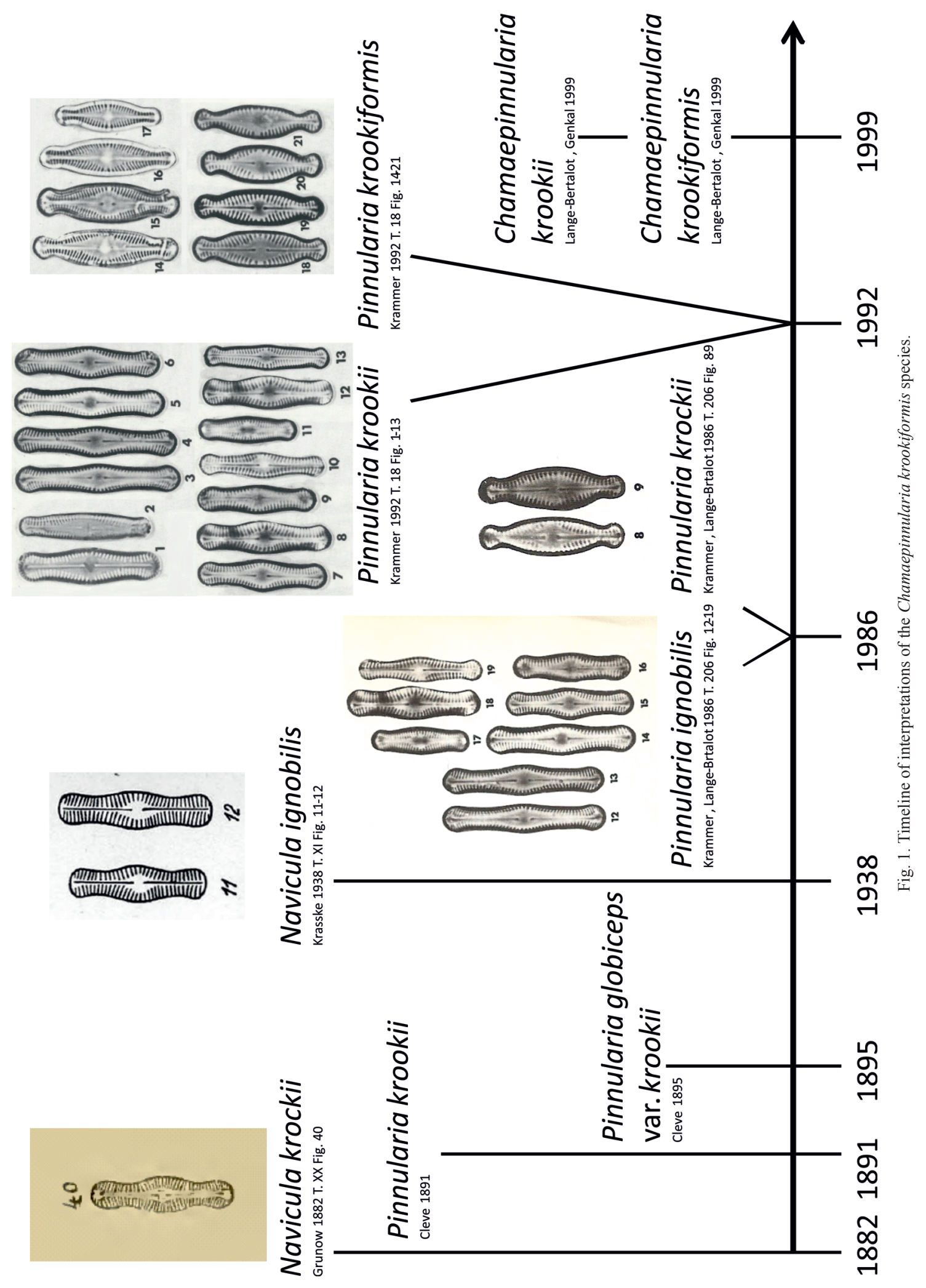




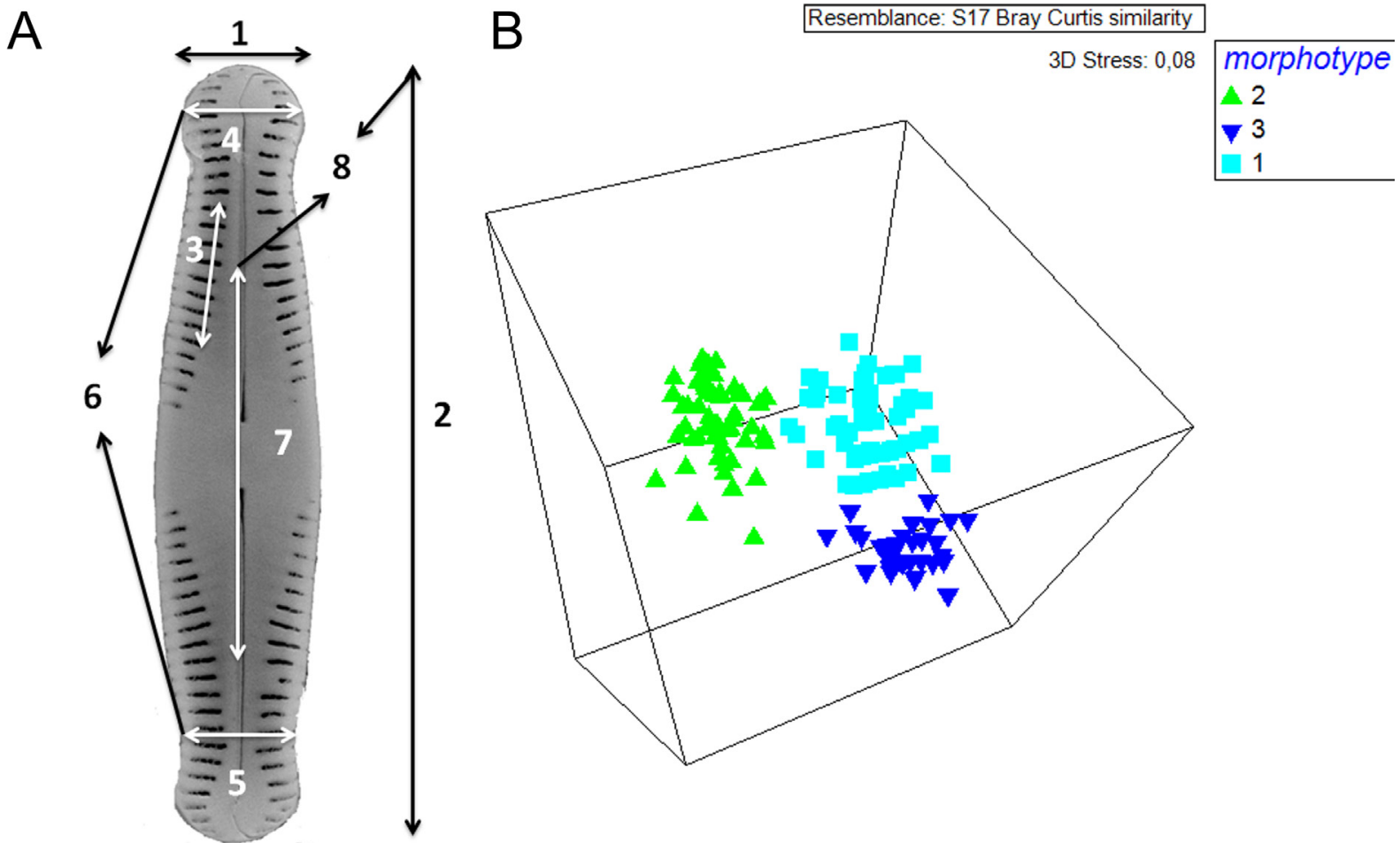

Fig. 2. The MDS procedure distinguished three groups of specimens based on eight features: (A) morphological features: (1) valve width and (2) length, (3) number of striae in $10 \mu \mathrm{m}$, (4) width of capitate apices, (5) width of constrictions, (6) ratio of apices width to constrictions width, (7) length of central area, and (8) ratio of the valve length to the central area length; (B) MDS analysis revealed three morphotypes of Chamaepinnularia krookiformis.

to $19.49 \mathrm{mg} . \mathrm{l}^{-1}$. This species was noted in the costal shallows of Puck Bay (WITKOwSKI 1994, p. 176-177, plate XXXVIII, fig. 16-17) where the concentration of chloride ions was higher. ŻELAZNA-WIECZOREK (2011) identified several specimens of this species in samples from springs; however, in samples from the Puck Bay the presence of this species was noted from rare to frequent (WITKOWSKI 1994). In the present research, the species percentage exceeded $10 \%$ in samples from the ditch. Since Chamaepinnularia plinskii occurs largely in waters with an increased concentration of chloride ions (over $1000 \mathrm{mg} . \mathrm{l}^{-1} \mathrm{Cl}^{-}$), according to the halobion system of VAN DER WERFF and Huls 1957-1974 (DENYS et al. 1983; ŻELAZNA-WIECZOREK et al. 2015) Chamaepinnularia plinskii can be classified as a brackish species (the $4^{\text {th }}$ category of salinity). Chamaepinnularia plinskii occurred in a habitat which dries up periodically. According to VAN DAM et al. (1994), the classification of this species can be described as typical for wet and moist or temporarily dry habitats (the $4^{\text {th }}$ category of moisture).

\section{Chamaepinnularia krookiformis (KRAMMER) LANGE- Bertalot et Krammer 1999 (tafel 45, fig. 6-10)}

\section{Description species according to KRAMMER 1992}

Valve length 14-40 $\mu \mathrm{m}$; valve width 5-11 $\mu \mathrm{m}$; number of striae 17-21/10 $\mu \mathrm{m}$; ratio of the length to the width 2.8-4. The valve is elliptic in shape, convex, ends of the valve are rounded with constrictions. The axial area is narrow; the central area is wide and of rhomboid-elliptic shape. The raphe is straight and filiform.

Based on the MDS analysis two morphological forms defined as: Morphotype 2 and Morphotype 3, Chamaepinnularia krookiformis have been distinguished (Fig. 2B). Morphotype 2 (Fig. 20-31) and Morphotype 3 (Fig. 32-49).

Description: LM: the main differentiating feature of Morphotype 2 from Morphotype 3 is the central area length and width. In Morphotype 2, the central area dimensions are 6-10 $\mu \mathrm{m}$ in length and 2-3.5 $\mu \mathrm{m}$ in width. In specimens belonging to Morphotype 3, the central area dimensions are 11-14 $\mu \mathrm{m}$ in length and 2.5-5.0 $\mu \mathrm{m}$ in width; the ratio of the valve length to the central area length is 1.4-1.9. Morphotype 3 has more capitate apices than Morphotype 2 (Table 2).

SEM: Externally, striae are composed of simple, chamber-like areole, with external openings covered by vela. The valve striae are separated from the mantle striae by a hyaline area along the entire valve circumference. The raphe is straight, its proximal endings have a tear drop shape. Distal raphe endings are hooked in the case of Morphotype 2 (Figs 53-55), while they are strongly hooked in the case of Morphotype 3 (Figs. 56-58). Internal view: striae make foramina, they are arranged in the same way as those on the ex- 

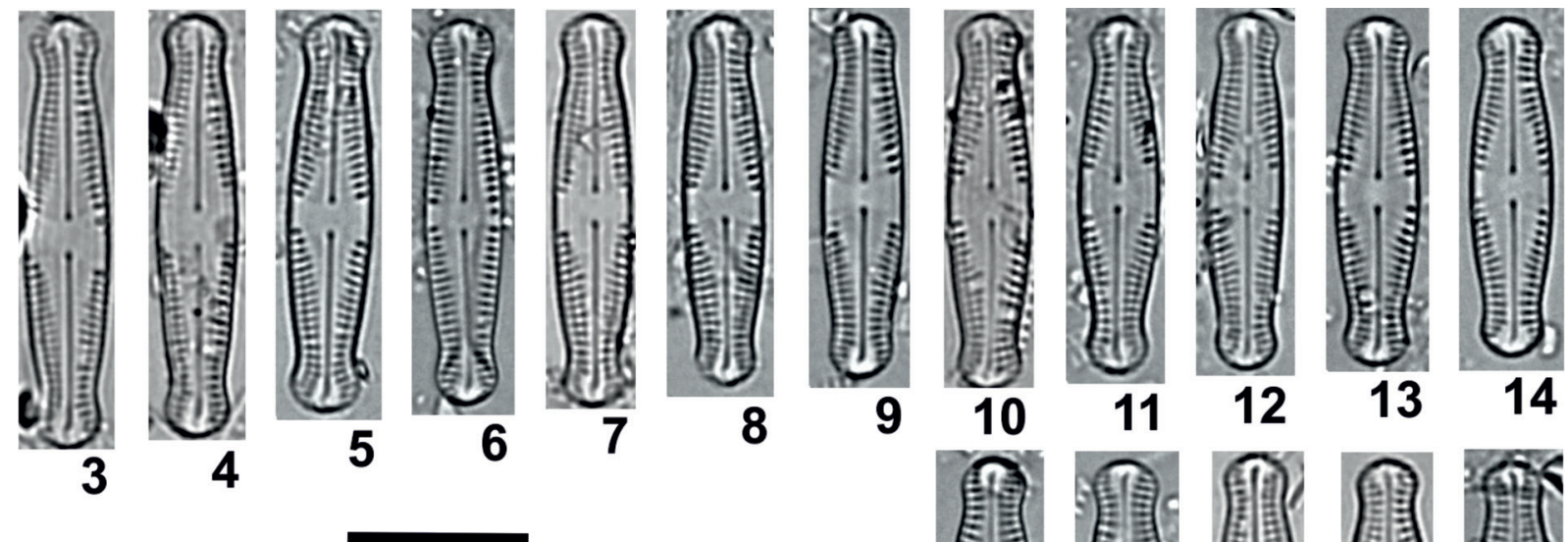

14
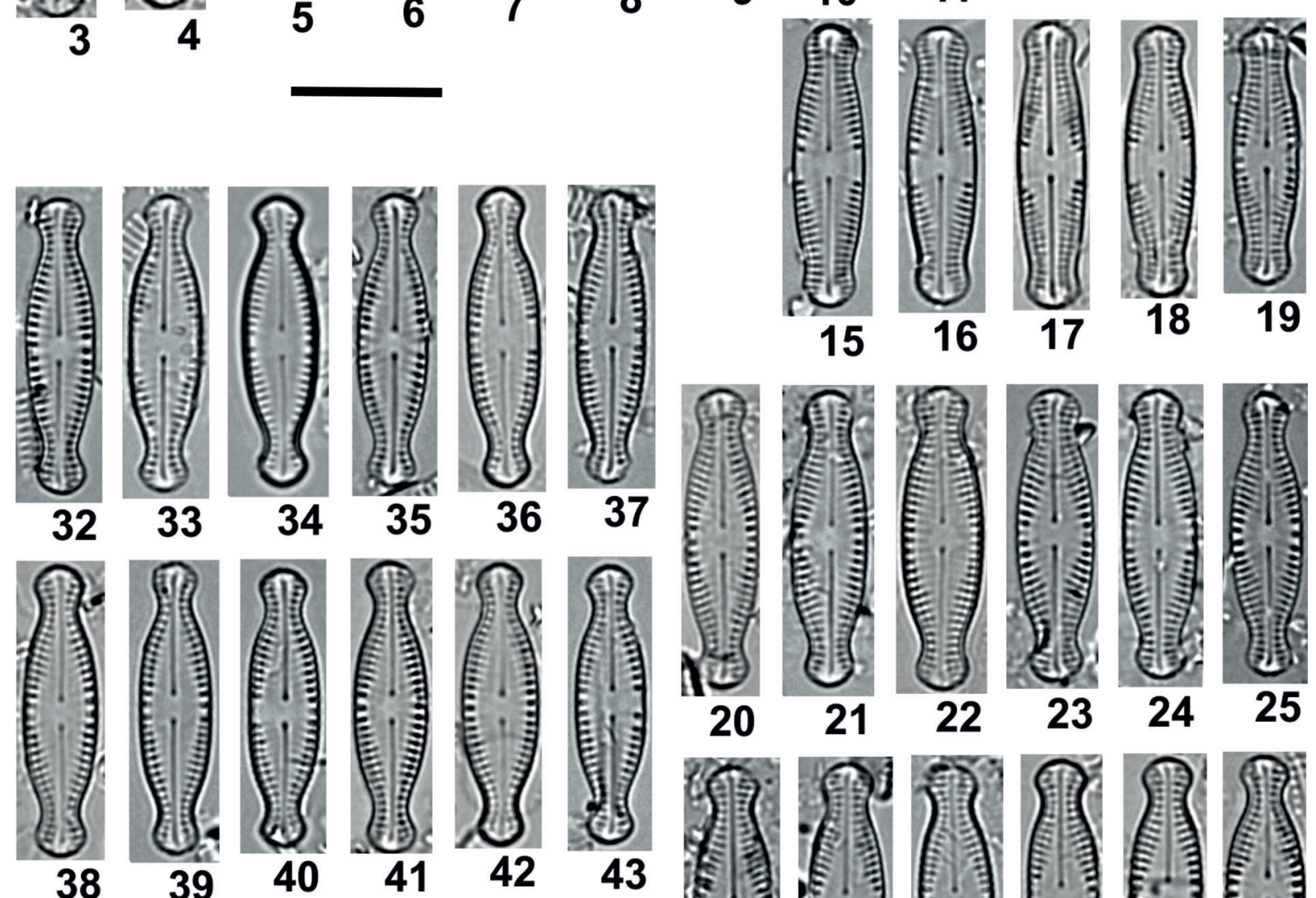

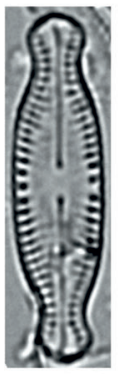
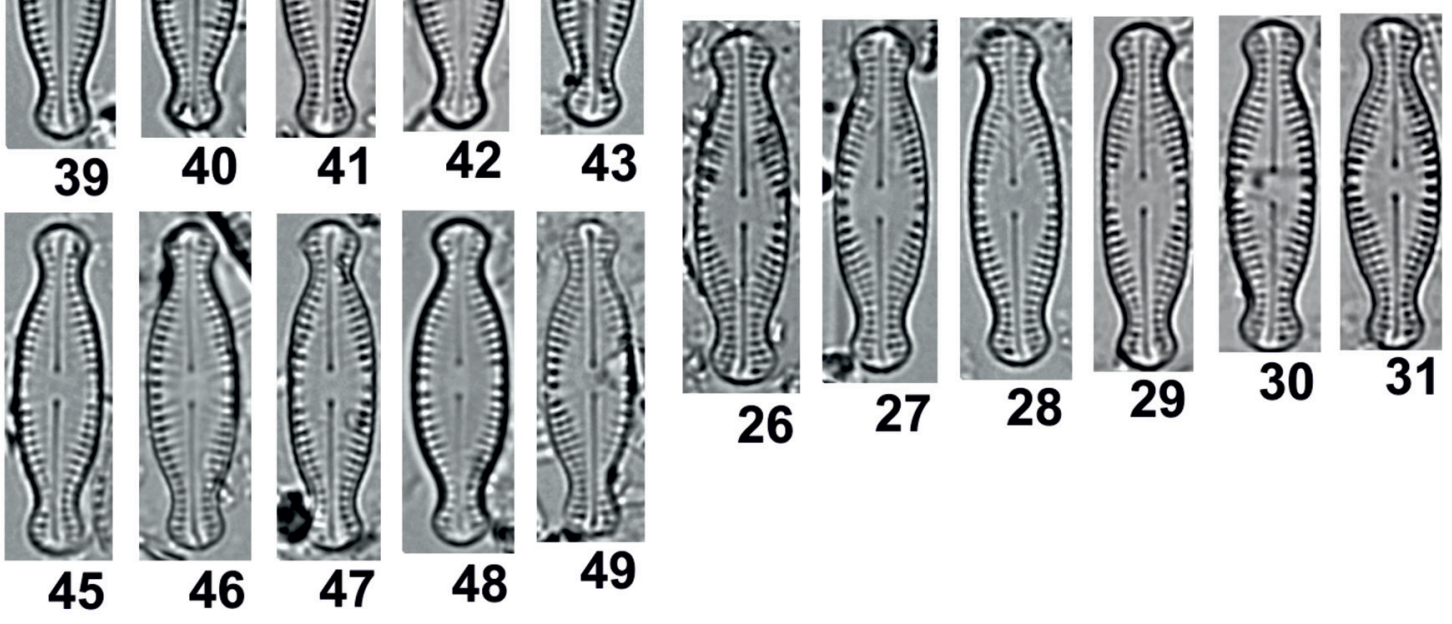

Figs 3-49. LM photomicrographs of Chamaepinnularia species: (3-19) Chamaepinnularia plinskii sp. nov. (Morphotype 1); (20-31) Chamaepinnularia krookiformis - Morphotype 2; (32-49) Chamaepinnularia krookiformis - Morphotype 3. Scale bar $10 \mu \mathrm{m}$.

ternal side. Striae on the valve face are interrupted and separated by a silica bridge to form two parts, the first one is small and rounded and is located on the valve face-mantle junction, the second one is elongated, and located on the valve face. Raphe is straight, distal endings form a helictoglossa, the proximal ones are hooked in the same direction.
Specimens from the type material of Pinnularia krookiformis correspond to both morphotypes in the recent material: Morphotype 2 (Figs 62-69) and Morphotype 3 (Figs 70-77). The analysis of morphological features of Morphotypes 2 and 3 in SEM (Figs 59-61) allows a high similarity between the type and recent material to be confirmed. However, the valve dimensions in the 


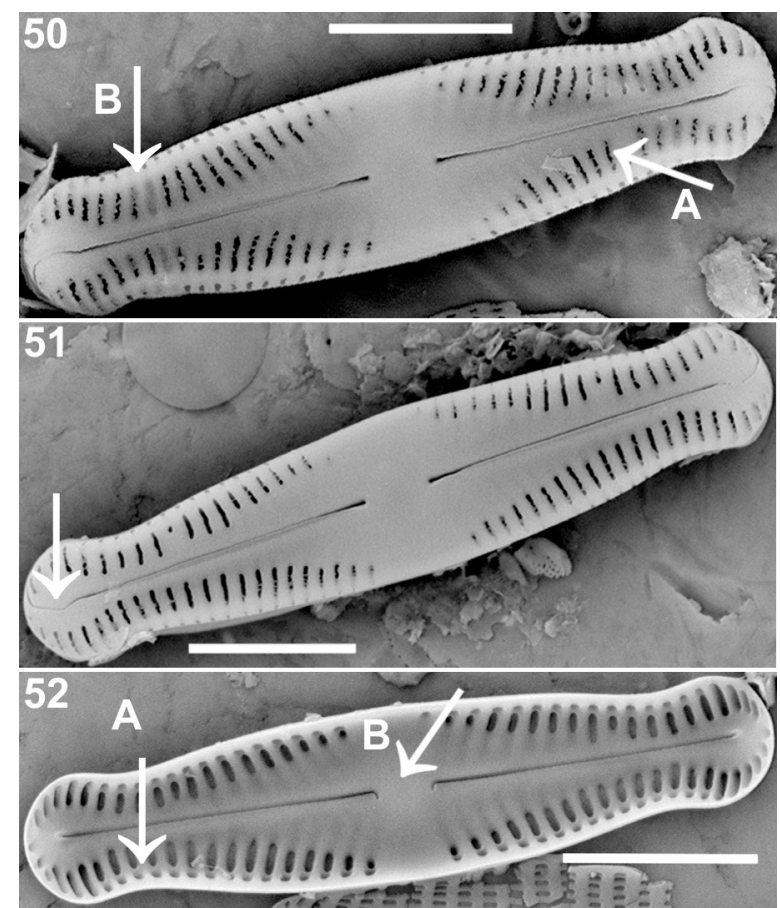

Figs 50-52. SEM images of Chamaepinnularia plinskii sp. nov. from Pełczyska (Central Poland): (50) External view, (arrow A) striae composed of chamber-like areola and covered by vela, (arrow B) striae on the valve face separate from the mantle striae by a hyaline area; (51) external view, (arrow) distal raphe endings hooked, curving down to the mantle; (52) internal view, (arrow A) silica bridge, divided areola, (arrow B) thick sternum forming a fascia. Scale bars $5 \mu \mathrm{m}$.

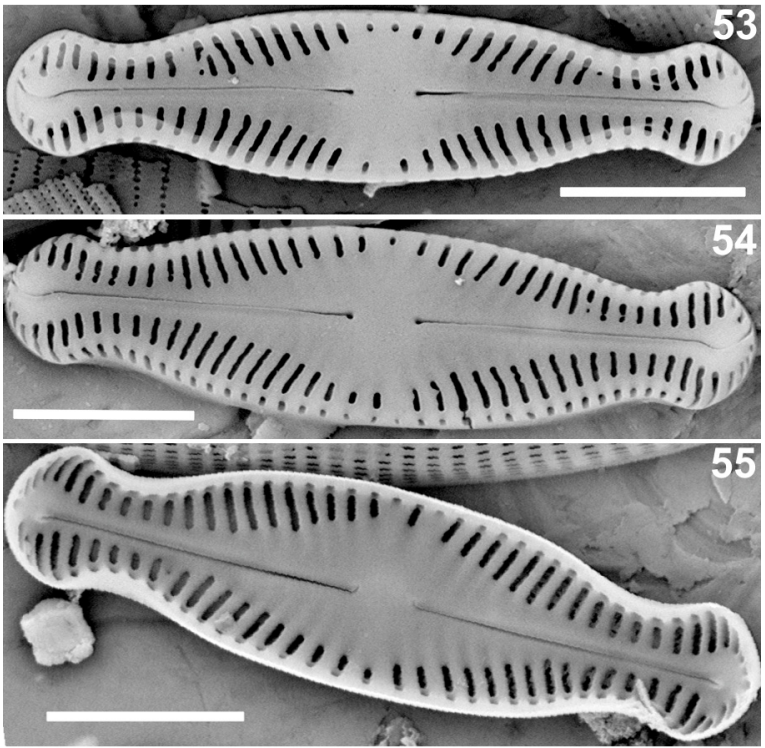

Figs 53-55. SEM images of Chamaepinnularia krookiformis - Morphotype 2 from Pełczyska (Central Poland): (53-54) internal view, chamber-like areola, tear-drop-shaped proximal raphe endings, distal raphe endings hooked; (55) internal view, distal raphe endings form helictoglossa, the proximal ones are hooked and turned towards the same valve edge. Scale bars $5 \mu \mathrm{m}$.

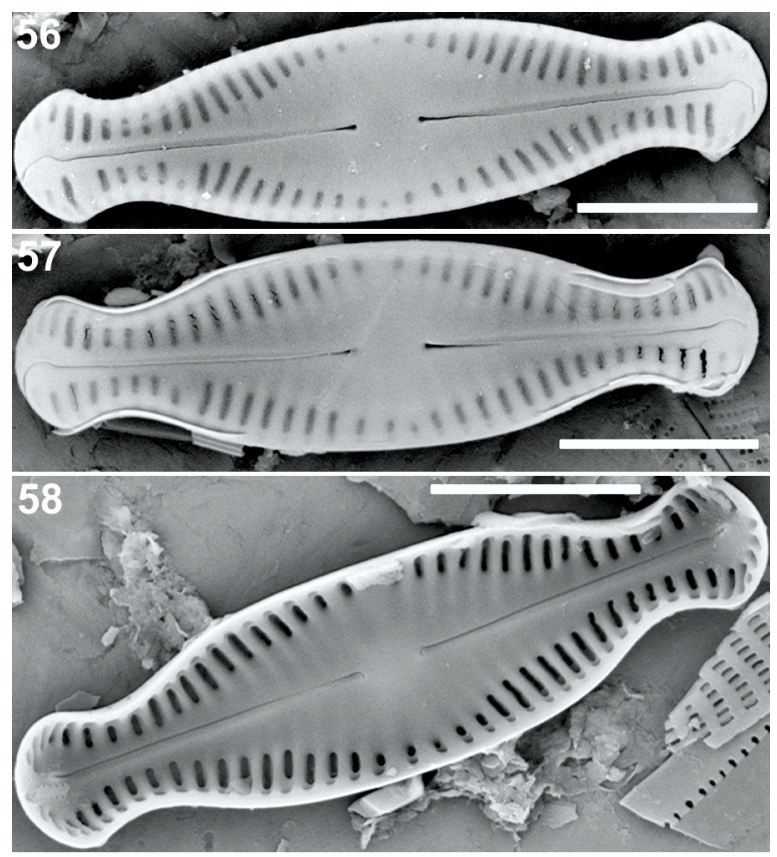

Figs 56-58. SEM images of Chamaepinnularia krookiformis - Morphotype 3 from Pełczyska (Central Poland): (56-57) internal view, chamber-like areola, tear-drop-shaped proximal raphe endings, distal raphe endings strongly hooked; (58) internal view, distal raphe endings form helictoglossa, the proximal ones are hooked and turned towards the same side of the valve. Scale bars $5 \mu \mathrm{m}$.

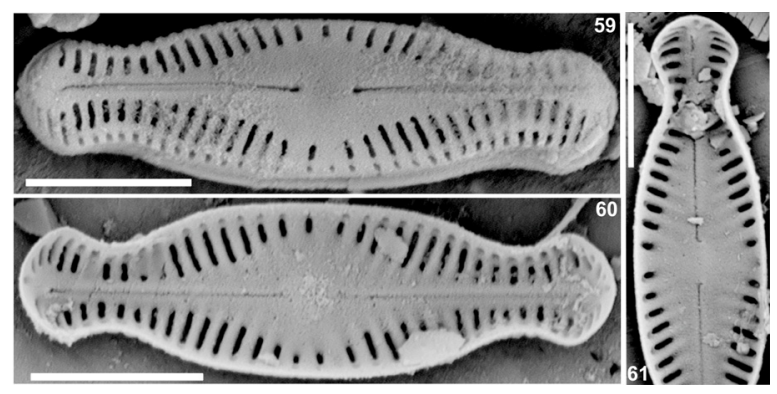

Figs 59-61. SEM photomicrographs of the type material of Pinnularia krookiformis KRAMMER from Germany [=Chamaepinnularia krookiformis (Krammer) Lange-Bertalot et Krammer 1999]: (59) valve external view, (60) valve internal view; (61) valve internal view with hooked distal raphe endings. Scale bars $5 \mu \mathrm{m}$.
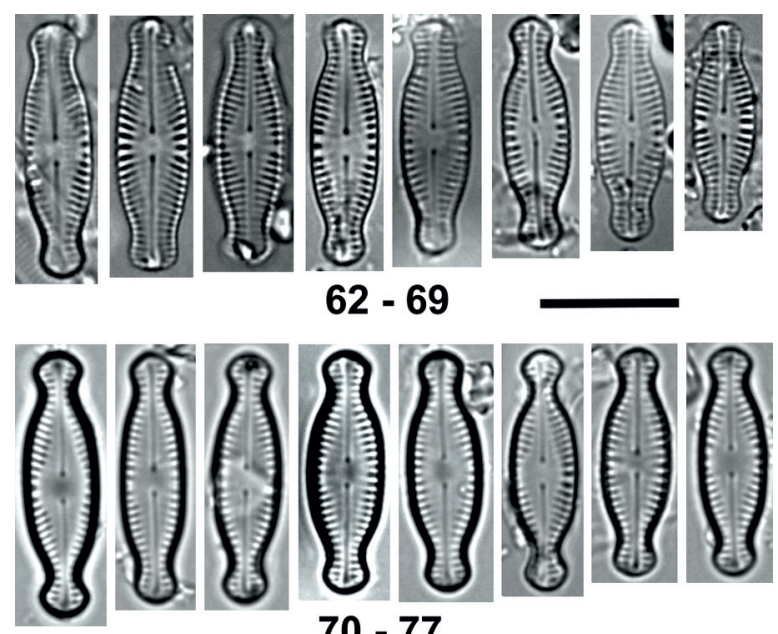

$62-69$

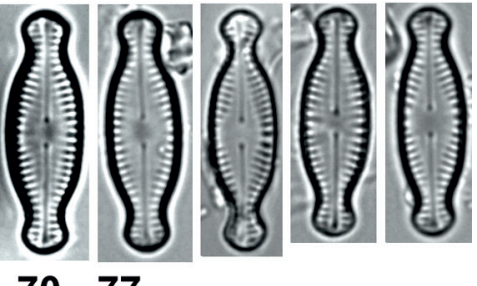

$70-77$ 
recent and type material are narrower (length 14-22 $\mu \mathrm{m}$ and width 4-5 $\mu \mathrm{m}$ ) than those given in the description by KRAMMER (1992) for Pinnularia krookiformis (lenght 14-40 $\mu \mathrm{m}$, width 5-11 $\mu \mathrm{m}$ ).

\section{SuMmary}

In the athalassic habitats studied, a wide morphological variability of forms earlier classified as Chamaepinnularia krookiformis was observed. The analysis allowed three morphotypes to be distinguished. Morphotype 1 was distinguished as a new species, Chamaepinnularia plinskii, based on the following most important features: the presence of a wide fascia reaching the valve margin, number of striae in $10 \mu \mathrm{m}$, wider apical constrictions, and a lower ratio of valve length to central area width. However, features differentiating the two Morphotypes (2 and 3 ) have not provided a sufficient basis for distinguishing them as separate species.

Chamaepinnularia plinskii and C. krookiformis, occurred in the same habitats in Pełczyska. In Poland, the species were noted in various types of ecosystems as Chamaepinnularia krookiformis; however, the analysis of micrographs in publications enables their verification and classification as Chamaepinnularia krookiformis and $C$. plinskii. ŻELAZNA-WIECZOREK (2011) observed both species in the springs of the Lódź Hills, i.e.: Chamaepinnularia plinskii as $C$. cf. krookiformis (plate 103, fig. 34) and Chamaepinnularia krookiformis - Morphotype 3 (plate 103, figs 35-36). WoJTAL (2009) noted Chamaepinnularia krookiformis in the Kobylanka River; however, the photomicrographs documentation does not provide sufficient information for the correct classification of Morphotypes 2 and 3 (p. 164, plate 26, fig. 5; plate 82, fig. 3). In Puck Bay, WITKOWSKI (1994) could also observe the occurrence of Chamaepinnularia krookiformis Morphotype 2 (plate XXXVIII, figs 14-15) and Chamaepinnularia plinskii (Plate XXXVIII, Figs 16-17).

Chamaepinnularia plinskii is a species occurring in various types of aquatic ecosystems which dry up periodically; however, conditions favorable for its development are alkaline water with high chlorides concentrations.

\section{REFERENCES}

Bąk, M.; Witkowski, A. \& Lange-Bertalot, H. (2006): Diatom flora diversity in the strongly eutrophicated and $\beta$-mesosaprobic waters of the Szczecin Lagoon, NW Poland, southern Baltic Sea. - In: OgnJanovaRumenova N. \& Manoylov K. (eds): Advances in Phycological Studies, Festschrift in Honour of Professor Dobrina Teminskova-Topalova. - pp. 293-317, Pensoft Publishers \& University Publishing House, Sofia - Moscow.

Cantonati, M. \& Lange-Bertalot, H. (2009): On the ultrastructure of Chamaepinnularia schauppiana LANGEBertalot \& Metzeltin (Naviculaceae s.1.). - Diatom Research 24: 225-231.

Cleve, P.T. (1891): The diatoms of Finland. - Acta Societatia pro Fauna et Flora Fennica 8: 1-70.

Cleve, P.T. (1895): Synopsis of the naviculoid diatoms 27/2. - 219 pp., Kongl. Svenska Vetenskaps-Akademiens Handlingar, Stockholm.

Denys, L.; Lebbe, L.; Sliggers, B. C.; SpainK, G.; van StriJDONCK, M. \& Verbruggen, C. (1983): Litho- and biostratigraphical study of quaternary deep Marine deposits of the Western Belgian coastal plain. - Bulletin de la Sociětě belge de Gěologie 92: 125-154.

Grunow, A. (1882): Beiträge zur Kenntnis der fossilen Diatomeen Österreich-Ungarns. - In: MoJsISORICs, E. \& Neumayer, N. (eds): Beiträge zur Paläontologie 2/4. - 155, pl. XXX, Österreich-Ungarns und des Orients.

Fránková, M.; Bojková, J.; PoulíčKová, A. \& Hájek, M. (2009): The structure and species richness of the diatom assemblages of the Western Carpatian spring fens along the gradient of mineral richness. - Fottea 9: $355-368$

Kapetanović, T.; JAHN, R.; ReDŽIĆ, R.J. \& CARIĆ, M. (2011): Diatoms in a poor fen of Bijambare protected landscape, Bosnia \& Herzegovina. - Nova Hedwigia 93: $125-151$.

KrassKe, K. (1938): Beiträge zur Kenntnis der DiatomeenVegetation von Island und Spitzsbergen. - Archiv für Hydrobiologie 33: 503-533.

Krammer, K. (1992): Pinnularia. Eine Monographie der europäischen Taxa - Bibliotheca Diatomologica 26. 353 pp., J. Cramer, Berlin-Stuttgart.

Krammer, K. (2000): The genus Pinnularia. - In: LangeBertalot, H. (ed.): Diatoms of Europe 1. -707 pp., A.R.G. Gantner Verlag K.G., Ruggell.

Krammer, K. \& Lange-Bertalot, H. (1986): Bacillariophyceae. Teil 1: Naviculacea. - In: EtTl, H.; Gerloff, J.; Heynig, H. \& Mollenhauer, D. (eds): Süßwasserflora von Mitteleuropa 2/1. - 876 pp., Gustav Fisher Verlag, Stuttgart - New York.

Kulikovskiy, M.S.; Lange-Bertalot, H.; Witkowski, A.; DorofeyUK, N.I. \& GenKaL, S.I. (2010): Diatom assemblages from Sphagnum bogs of the world. I. Nur bog in northern Mongolia. - In: LANGE-Bertalot, H. \& Kociolek, P. (eds): Bibliotheca Diatomologica 55.

Figs 62-77. LM photomicrographs of type material of Pinnularia krookiformis KRAMMER from Germany [=Chamaepinnularia krookiformis (Krammer) Lange-Bertalot et Krammer 1999]: (62-69) LM photomicrographs of specimens corresponding to Chamaepinnularia krookiformis Morphotype 2 from recent material; (70-77) LM photomicrographs of specimens corresponding to Chamaepinnularia krookiformis Morphotype 3 from recent material. Scale bar 10 $\mu \mathrm{m}$.

\section{- 326 pp., J. Cramer, Stuttgart.}

Lange-Bertalot, H. \& Genkal, S.I. (1999): Diatoms from Siberia I. - In: LANGE-Bertalot, H. (ed): Iconographia Diatomologica 6. -292 pp., A.R.G. Gantner Verlag K.G., Vaduz.

Lange-Bertalot, H. \& Metzeltin, D. (1996): Indicators of Oligotrophy. - In: LANGe-Bertalot, H. (ed): Icono- 
graphica Diatomologica 2. - 390 pp., Koeltz Scientific Books, Königstein.

Peszek, Ł.; Noga, T.; Stanek-Tarkowska, J.; Pajączek, A.; Kochman-KęDziora, N. \& PieniążeK, M. (2015): The effect of antrophogenic change in the structure of diatoms and water quality of the Żołynianka and Jagielnia streams. - Jurnal of Ecological Engineering 16: 33-51.

PLIŃski, M. (1969): Okrzemki słonego źródła w Pełczyskach pod Ozorkowem. - Zesz. Nauk. UŁ 2(31): 123-136.

Sterken, M.; Verleyen, E.; Jones, V.J.; Dominic, A.H.; Vyverman, W.; SabBe, K. \& VAn de ViJver, B. (2015): An illustrated and annotated checklist of freshwater diatoms (Bacillariophyta) from Livingstone, Signy and Beak island (Maritime Antarctic Region). - Plant Ecology and Evolution 148: 431-455.

Wetzel, C.E.; Martínez-Carreras， N.; Hlúbiková, D.; Hoffmann, L.; Pfister, L. \& Ector, L. (2013): New combinations and type analysis of Chamaepinnularia species (Bacillariophyceae) from aerial habitats. Cryptogamie, Algologie 34: 149-168.

Witkowski, A. (1994): Recent and fossil diatom flora of the Gulf of Gdańsk, Southern Baltic Sea. In: Bibliotheca Diatomologica 28. - 313 pp. Cramer, Berlin, Stuttgart.

Witkowski, A.; Lange-Bertalot, H. \& Metzeltin, D. (2000): Diatom flora of marine coasts I. In: LANGE-BERTALOT, H. (ed) Iconographia Diatomologica 7. - 925 pp., A.R.G. Gantner Verlag K.G.
Wojtal, A.Z. (2009): The diatoms of Kobylanka stream near Kraków (Wyżyna Krakowsko-Częstochowska upland, S Poland). - Polish Botanical Journal 54: 129-330.

Van Dam, H.; Mertens, A. \& SinKeldam, J. (1994): A coded checklist and ecological indicator values of freshwater diatoms from the Netherlands. - Netherlands Jurnal of Aquatic Ecology 28: 117-133.

VAn de Vijver, B.; Sterken, M.; Vyverman, W.; Mataloni, G.; Nedbalová, L.; Kopalová, K.; Elster, J.; VerLEYen, E. \& SABBE, K. (2010): Four new non-marine diatom taxa from the Subarctic and Antarctic regions. - Diatom Research 25: 431-443.

Żelazna-WieczoreK, J. (2002): Vaucheria species in selected regions in Poland. - Acta Societatis Botanicorum Poloniae 71: 129-139.

Żelazna-WieczoreK J. (2011): Diatom flora in springs of Łódź Hills (Central Poland). - In: WitKowski, A. (ed): Diatom Monographs 13. - 419 pp., A.R.G. Gantner Verlag K.G., Ruggell, Liechtenstein.

Żelazna-Wieczorek, J.; Olszyński, R.M. \& NowickAKRAWCZYK, P. (2015): Half a century of research on diatoms in athalassic habitats in central Poland. - Oceanological and Hydrobiological Studies 441: $51-67$.

(C) Czech Phycological Society (2016)

Received December 12, 2015

Accepted January 2, 2016 